\title{
Inquiry-Based Labs Using Paper Microfluidic Devices: The MICRO Project
}

Rachel M. Roller, Saichon Sumantakul, Michelle Tran, Andrea Van Wyk, Jessica Zinna, Destiny A. Donelson, Sarah G. Finnegan, Gregory Foley, Olivia R. Frechette, Jessica Gaetgens, Jiani Jiang, Katheryn C. Rinaolo, Reneé S. Cole, Marya Lieberman, Vincent T. Remcho, Kimberley A. Frederick*

\section{ABSTRACT}

The Making Introductory Courses Real while Online (MICRO) laboratory project was developed to meet the need for hands-on experiments, focused on topics in analytical chemistry, to be delivered safely remotely or in a socially distanced in-person lab. Unlike more traditional lab kits, MICRO labs use only microgram or nanogram amounts of chemicals; paper microfluidic technology is used to store and mix reactants. Instructional materials use an inquiry-based approach and are situated in a context that highlights the human impacts of the scientific analysis. To support broader-scale implementation of the experiments and promote a shift to more inquiry-based laboratory instruction, an array of supports was developed, including adaptable instructional materials, instructional videos for lab preparation, resource guides, and an introductory workshop. A cohort of nine institutions implemented MICRO labs both remotely and in person during Fall 2020. Students were able to successfully complete the experiments and the inquiry nature of the labs led to an increased comfort with the trialand-error nature of authentic scientific practice. Additionally, most faculty participants indicated a commitment to an increased degree of inquiry in their laboratory pedagogy.

\section{GRAPHICAL ABSTRACT}

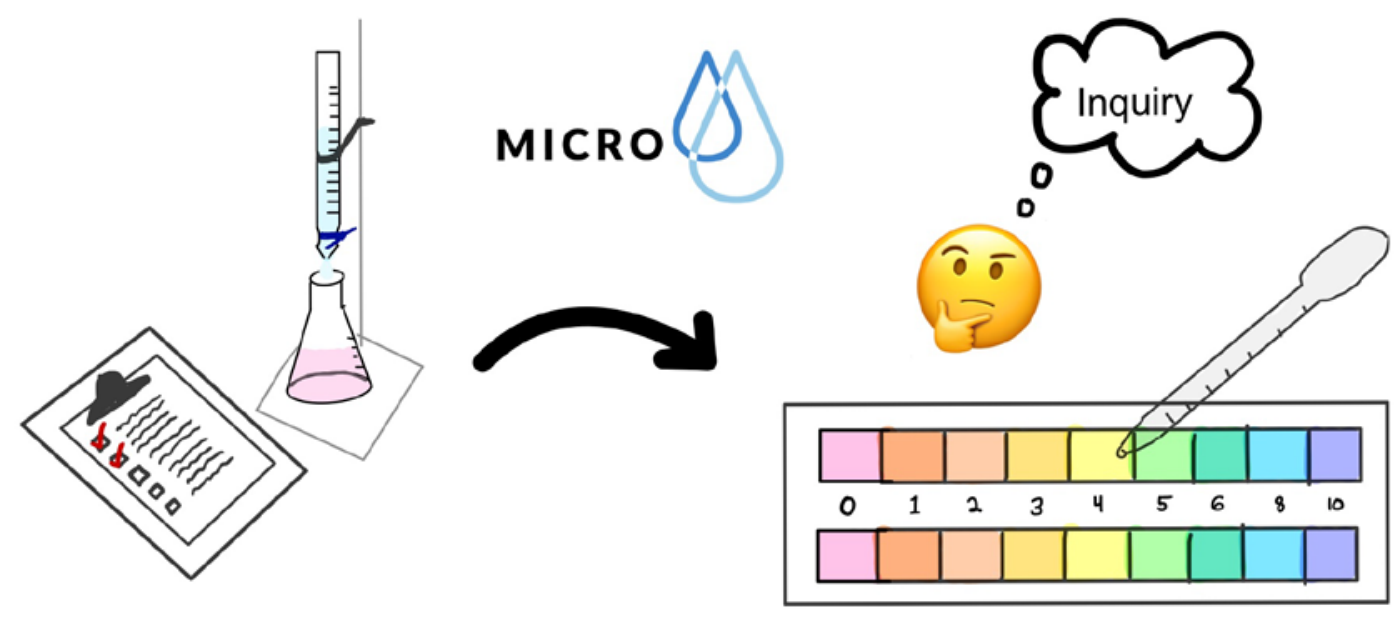




\section{KEYWORDS}

Second-Year Undergraduate, Analytical Chemistry, Laboratory Instruction, Inquiry-Based/Discovery Learning, Problem Solving/Decision Making, Quantitative Analysis, Distance Learning/Self Instruction, Professional Development, Microscale Lab

In the wake of the COVID-19 pandemic, STEM educators have been forced to find creative ways to deliver quality laboratory instruction at a distance. This was especially challenging in analytical chemistry laboratories such as quantitative analysis and instrumental analysis that rely heavily on wet chemical methods and specialized equipment. Strategies widely used in introductory chemistry courses, such as watching videos and analyzing old data sets, ${ }^{1-4}$ left some analytical students frustrated and disengaged, ${ }^{5}$ prompting many analytical instructors to turn to simulations, ${ }^{5,6}$ statistical analysis of previously collected data, ${ }^{7,8}$ or some combination thereof. ${ }^{9}$ A few educators created at-home experiments with safe, readily available materials such as food coloring ${ }^{10}$ or used "lab-in-a-box" kits containing glassware, chemicals, and even a spectrophotometer, ${ }^{11}$ but very few hands-on options were available.

The Making Introductory Courses Real while Online (MICRO) project sprang from our desire to create safe, affordable, hands-on laboratory experiences for distance learning in analytical chemistry. We aimed to develop laboratories that were more hands-on than videos and simulations and more rigorous than "kitchen chemistry" experiments, but also safer, cheaper, and more open-ended than at-home laboratory kits, ${ }^{11-15}$ which can cost several hundred dollars each and require strict adherence to step-by-step, “cookbook-style” procedures to avoid liability issues. The MICRO project harnesses the emerging technology of paper microfluidics to create safe, hands-on labs that also allow students to develop authentic scientific skills using an inquiry-based approach.

\section{BACKGROUND}

\section{Inquiry-Based Learning}

While the sudden switch to distance learning brought challenges, we viewed it as an opportunity to create analytical chemistry laboratory materials that not only met the need for safe, at-home laboratories, but also incorporated evidence-based pedagogical practices such as inquiry-based laboratory learning. ${ }^{16-22}$ One benefit of inquiry-based laboratory experiments is that they allow students to engage in authentic scientific practices. In 2012, the National Academies published A Framework for K-12 Science Education, ${ }^{23}$ which provides guidance for K-12 learning but applies to higher education as well. ${ }^{23-26}$ This framework identifies eight scientific and engineering practices, such as asking questions, planning investigations, and analyzing and interpreting data, which go beyond content knowledge to embody the skills scientists use in actual research. ${ }^{23}$ These are the types of skills employers value when hiring STEM graduates, so they should form an integral part of any laboratory course that aims to prepare students for future careers. ${ }^{27,28}$ 
Opportunities to engage in these practices are very limited in traditional, cookbook-style laboratory experiments. ${ }^{23,29,30}$ In a cookbook-style lab, students are given the research question (if a question is provided at all), background information, step-by-step experimental procedures, and a framework for data analysis; the only tasks left to the students are following directions and reporting their results. ${ }^{29}$ In contrast, inquiry-based experiments are more open-ended, requiring students to make key decisions in the experimental process. Guided inquiry experiments can be more structured when students are learning a new technique, or almost completely open-ended when students design and conduct experiments to answer their own unique research questions. ${ }^{29} \mathrm{~A}$ 2019 study by Carmel et al. found that inquiry-based laboratory curricula provide more opportunity than traditional labs for students to engage in scientific practices rather than passively observing the experimental process. ${ }^{31}$ Inquiry-based laboratory frameworks such as the Science Writing Heuristic ${ }^{19}$ and Argument-Driven Inquiry ${ }^{21,22}$ have been shown to produce better learning outcomes, ${ }^{17,22}$ especially among minoritized students and those who struggled in previous courses. ${ }^{22,32}$

Despite the increase of publications in educational journals such as the Journal of Chemical Education encouraging the use of guided-inquiry and open-inquiry laboratory experiments, cookbook-style laboratory experiments continue to dominate undergraduate laboratory curricula. In two studies by Bruck, Bretz, and Towns, it was determined that $92 \%$ of STEM laboratory experiments and $89 \%$ of chemistry laboratory experiments are either confirmation laboratory experiments or cookbook-style laboratory experiments. ${ }^{29,30}$ Because of this, designing inquiry-based laboratory experiments and providing faculty with training and support to transform existing laboratory experiments to be more inquiry-based is a priority for the MICRO project.

\section{Social Justice as a Context for Laboratory Materials}

Another specific focus of the MICRO project's materials is to explore ways in which science can contribute to social justice in the context of historical injustice and oppression. Several researchers have advocated integrating social justice into STEM education as a way to better train and engage students from all backgrounds. ${ }^{33,34}$ At present, published articles with these contexts are quite limited. ${ }^{35-37}$ Each experiment in the MICRO project includes background information linking the scientific concepts to a relevant social justice concern such as food insecurity, medical research disparities, and access to clean water (see Table 1). Background information about the issue and its differential impact on different communities is provided along with resources for students who would like to learn more or get involved. Faculty have opportunities to link to these issues in their post-lab assignments as an alternative mode of assessment. Pre-lab materials also include video interviews with scientists from a wide variety of identity categories, highlighting the journeys of these scientists and the obstacles they have overcome. 


\section{Paper Microfluidics as a Safe and Flexible Lab-Delivery Platform}

Microfluidic paper analytical devices ( $\mu$ PADs) offer an attractive platform for distance laboratory experiments due to their low cost, ease of fabrication, portability, safety, and user-friendliness. Nano- to microgram quantities of reagents can be safely embedded in the paper (similar to $\mathrm{pH}$ paper or aquarium test strips) and sent through the mail, minimizing concerns about chemical transport and disposal. Microfluidic devices are inexpensive and run quickly, so students have the freedom to repeat experiments as needed without worrying about trying something that may not work. Many $\mu \mathrm{PAD}$ assays use colorimetric detection that can be read with the naked eye or analyzed with a smartphone app for more quantitative readout. ${ }^{38}$ While microfluidic devices are limited in terms of their quantitative abilities, they provide opportunities to teach students valuable analytical principles such as calibration, uncertainty, error analysis, blanks, internal standards, and statistical analysis of replicate measurements.

Since Cai et al. piloted a paper microfluidic amino acid assay in an undergraduate instrumental laboratory course in 2013, ${ }^{39}$ interest in using paper microfluidics in undergraduate science education has been slowly growing. Ravgiala et al. used simple paper devices in a mock forensic investigation with middle and high school students, ${ }^{40}$ Koesdjojo et al. developed a colorimetric paper device for iron and copper detection in a first-year chemistry lab, ${ }^{38}$ and $\mathrm{Xu}$ et al. used a paper microfluidics platform to demonstrate electrophoretic separation in instrumental analysis. ${ }^{41}$ Recent innovative uses of paper microfluidics in analytical laboratory courses include detection of aluminum in gastric drugs by Lai et al., ${ }^{42}$ a smartphone-enabled colorimetric iron thiocyanate assay by Armenta et al., ${ }^{43}$ and detection of adulterated antibiotics by Bliese et al. ${ }^{44}$ The materials in this project make use of similar technology to develop a flexible set of experiments that can be delivered safely at-home or inperson.

\section{MICRO LABORATORY EXPERIMENTS}

The goal of the MICRO project is to make use of the relative safety and low cost of microfluidic technology to develop labs that foster active learning and cover many of the topic areas and laboratory techniques in a typical sophomore analytical course. All of the MICRO experiments were designed with several key experimental features. First, they make use of minimal equipment (e.g. an inexpensive balance, a fixed-volume micropipette, a cell phone camera, and a digital multimeter). With an eye toward cost and safety, each experiment is limited to microgram or nanogram amounts of chemicals without the need for organic solvents or larger quantities of other possibly hazardous substances. Finally, they encourage students to explore different aspects of analytical methods including preparing various types of standards (external, standard addition), performing different types of analyses (titrimetry, colorimetry, potentiometry), and determining figures of merit (detection limit, sensitivity, selectivity). A full listing of current experiments can be found in Table 1, and student handouts and instructor notes can be found in the supporting information. 


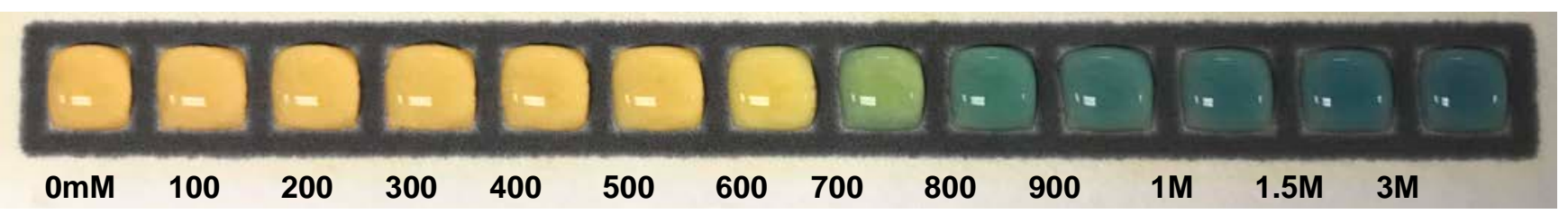

Figure 1. Paper analytical device for acid-base titrations.

One example of a $\mu \mathrm{PAD}$ developed for the MICRO project is shown in Figure 1. This paper titrator device, which can be used for both acid-base and reduction-oxidation titrations, is wax printed to create hydrophobic barriers and pre-loaded with known amounts of titrant. ${ }^{45}$ Students create an experimental plan by determining which region of the $\mu \mathrm{PAD}$ will give the most precise results, whether the sample needs to be diluted before analysis, how much sample to add to the $\mu \mathrm{PAD}$, and what the endpoint should look like visually. Determining the conditions that produce the best results can be done through careful pre-lab questions, an iterative trial-and-error procedure, or a combination of both strategies. The process of using the $\mu \mathrm{PAD}$ is rapid and straightforward, and results can be read by eye or with a color-detection cell phone application, so students can easily obtain multiple readings to calculate accuracy and precision.

\section{Table 1. Experiments Developed for the MICRO Project}

\begin{tabular}{|c|c|c|c|c|}
\hline Experiment & $\begin{array}{l}\text { Cultural } \\
\text { Context }\end{array}$ & Chemistry Concepts & $\begin{array}{l}\text { Instructor-Provided } \\
\text { Materials }^{\mathrm{a}}\end{array}$ & $\begin{array}{l}\text { Student-Provided } \\
\text { Materials }\end{array}$ \\
\hline Vinegar Titration & Acid rain & $\begin{array}{l}\text { Acid-base titration, pH, buffers, } \\
\text { dilutions, indicators }\end{array}$ & $\begin{array}{l}\text { Titrator devices preloaded } \\
\text { with } \mathrm{NaOH}, \mathrm{pH} \text { paper }\end{array}$ & $\begin{array}{l}\text { Vinegar, optional } \\
\text { cell phone }\end{array}$ \\
\hline $\begin{array}{c}\text { Ksp of Amphoteric } \\
\text { Salts }\end{array}$ & $\begin{array}{l}\text { Food deserts } \\
\text { and the right } \\
\text { to cook }\end{array}$ & $\begin{array}{l}\text { Solubility, equilibrium, Ksp, } \\
\text { amphoteric salts }\end{array}$ & $\begin{array}{l}\text { Titrator devices preloaded } \\
\text { with } \mathrm{NaOH}, \mathrm{pH} \text { paper }\end{array}$ & $\begin{array}{l}\text { Cream of tartar } \\
\text { and/or baking } \\
\text { soda, optional cell } \\
\text { phone }\end{array}$ \\
\hline $\begin{array}{l}\text { Milk Protein } \\
\text { Analysis }\end{array}$ & $\begin{array}{l}\text { Food } \\
\text { allergies }\end{array}$ & $\begin{array}{l}\text { Calibration curves, standard } \\
\text { addition, matrix effects, sample } \\
\text { pretreatment, flow-through } \\
\text { devices, colorimetric analysis }\end{array}$ & $\begin{array}{l}\text { Flow-through device holder } \\
\text { (3D printed or made from } \\
\text { washers and binder clips), } \\
\text { paper disks preloaded with } \\
\text { buffer, standards, and } \\
\text { indicator }\end{array}$ & $\begin{array}{l}\text { Milk (any } \\
\text { variety), coffee } \\
\text { filters, cell phone } \\
\text { with free color } \\
\text { analysis app }\end{array}$ \\
\hline $\begin{array}{l}\text { Bromide Water } \\
\text { Analysis }\end{array}$ & $\begin{array}{l}\text { Hydraulic } \\
\text { fracturing } \\
\text { and water } \\
\text { pollution }\end{array}$ & $\begin{array}{c}\text { Standard addition, matrix } \\
\text { effects, flow-through devices, } \\
\text { colorimetric analysis }\end{array}$ & $\begin{array}{l}\text { Flow-through device holder, } \\
\text { paper disks preloaded with } \\
\text { buffer, standards, and } \\
\text { indicator }\end{array}$ & $\begin{array}{l}\text { Water (distilled if } \\
\text { available), cell } \\
\text { phone with free } \\
\text { color analysis app }\end{array}$ \\
\hline $\begin{array}{l}\text { Copper } \\
\text { Electrochemistry }\end{array}$ & $\begin{array}{l}\text { Flint Water } \\
\text { Crisis }\end{array}$ & $\begin{array}{c}\text { Redox reactions, } \\
\text { electrochemical cells, Nernst } \\
\text { equation, serial dilutions, } \\
\text { logarithmic calibration curves }\end{array}$ & $\begin{array}{l}\text { Paper electrochemical cells, } \\
\text { paper disks preloaded with } \\
\text { copper(II) sulfate, digital } \\
\text { multimeter, copper wire }\end{array}$ & Cornstarch, salt \\
\hline $\begin{array}{l}\text { Iodometric } \\
\text { Vitamin C } \\
\text { Titration }\end{array}$ & $\begin{array}{l}\text { Food } \\
\text { insecurity } \\
\text { and nutrient }\end{array}$ & $\begin{array}{c}\text { Redox reactions iodometric } \\
\text { titrations, analyzing true } \\
\text { unknowns }\end{array}$ & $\begin{array}{l}\text { Titrator device preloaded } \\
\text { with triiodide anion }\end{array}$ & $\begin{array}{l}\text { Vitamin C tablets } \\
\text { and/or fruit juice, } \\
\text { cornstarch }\end{array}$ \\
\hline
\end{tabular}




\begin{tabular}{|c|c|c|c|c|}
\hline $\begin{array}{l}\text { Make-Your-Own } \\
\text { Microfluidic } \\
\text { Device }\end{array}$ & $\begin{array}{l}\text { Accessible } \\
\text { healthcare }\end{array}$ & $\begin{array}{c}\text { Hydrophobicity and } \\
\text { hydrophilicity, capillary flow } \\
\text { and intermolecular forces, } \\
\text { calibration }\end{array}$ & Filter paper & $\begin{array}{l}\text { Crayons, } \\
\text { aluminum foil, } \\
\text { food coloring, cell } \\
\text { phone with free } \\
\text { color analysis app }\end{array}$ \\
\hline
\end{tabular}

${ }^{a}$ All experiments assume simple equipment for volume delivery, such as a Beral pipette, an inexpensive milligram balance, and/or a fixed-volume pipette

Another example, shown in Figure 2, uses a flow-through microfluidic device ${ }^{46}$ to colorimetrically determine the protein concentration in milk. In addition to making colorimetric measurements with cell phone apps, the lab challenges students to explore different types of standards (external versus standard addition), dilutions, linear regression, and error analysis. Depending on the instructor's learning goals, the experiment can range from a relatively simple assay to an advanced exercise in method development.

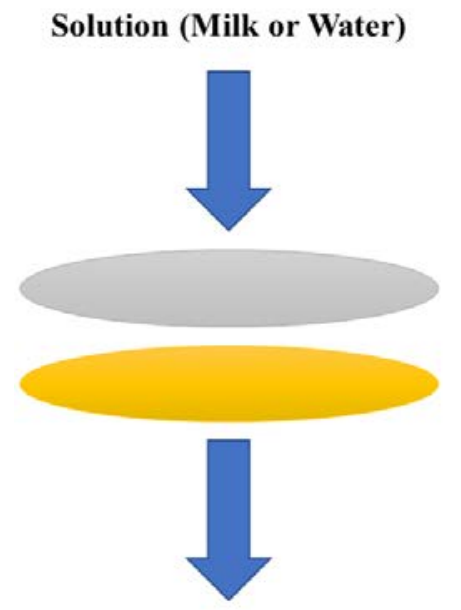

Colorimetric Result

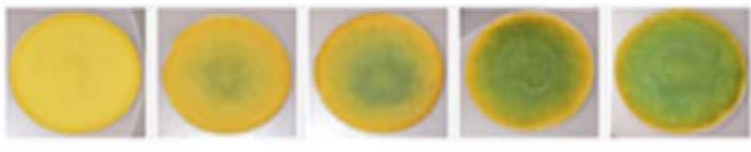

Buffer Layer

Standard or Blank with Indicator

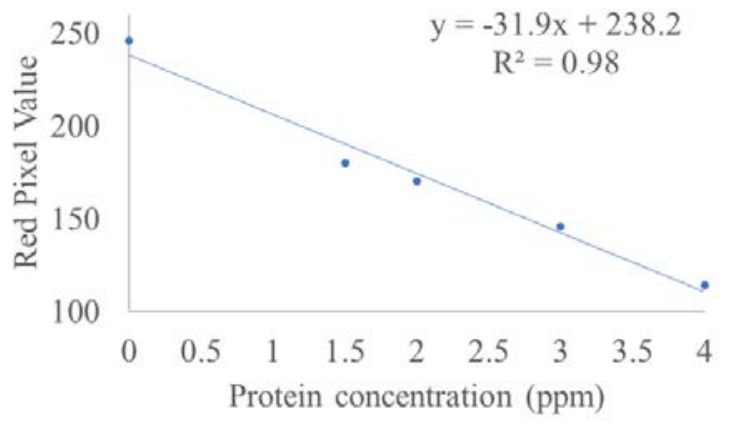

Figure 2. Flow-through device for quantification of protein in milk.

\section{SUPPORTING ADOPTION OF MATERIALS}

While the benefits of evidence-based instructional practices are clear in the literature, there has not been widespread adoption of evidence-based instructional practices in the classroom and laboratory. One potential reason for this "research-practice gap"32 is that faculty lack the training and time to successfully switch to active learning instructional techniques. ${ }^{47}$ Another issue is that change requires not only learning new instructional techniques but also adopting a new belief system. ${ }^{48}$ The typical avenues for academic communication are not proven to be effective in changing faculty beliefs. ${ }^{48}$ Therefore, we adopted a framework that has been shown to better support sustained adoption of educational materials and pedagogy. ${ }^{49}$ This has included leveraging the relative advantages of the MICRO experiments to support student experimentation, designing the experiments to be compatible with existing topics and practices, minimizing the complexity of implementation, and maximizing the trialability of the experiments. In addition, a collaborative teaching model such as a community of practice has 
also been shown to support sustained adoption. ${ }^{50-53}$ Therefore, our approach has been to create a community of practice among the instructors who attend the MICRO workshops and implement the MICRO labs in their analytical chemistry courses.

\section{Instructional Materials}

All of the materials developed through the MICRO project are customizable to the instructor's learning outcomes and available in an editable format or from an open-source website. ${ }^{54}$ Materials for each experiment contain possible learning outcomes, contextual background information related to social and scientific issues, inquiry-based student procedures, and pre- and post-lab questions linked to the lab’s learning outcomes. Information on the inquiry level of and scientific practices cultivated in each experiment can be found in the supporting information. Short video tutorials are available to introduce students to unfamiliar techniques, such as measuring voltage with a digital multimeter or using a color-capture app for image analysis. Instructor notes include detailed information on materials, lab preparation, paper device fabrication, sample data, and possible lab challenges. Templates for all of the wax-printed microfluidic devices are provided so that instructors can prepare $\mu$ PADs, and, if the course is being delivered remotely, ship them to students. An example MICRO lab kit can be seen in Figure 3.

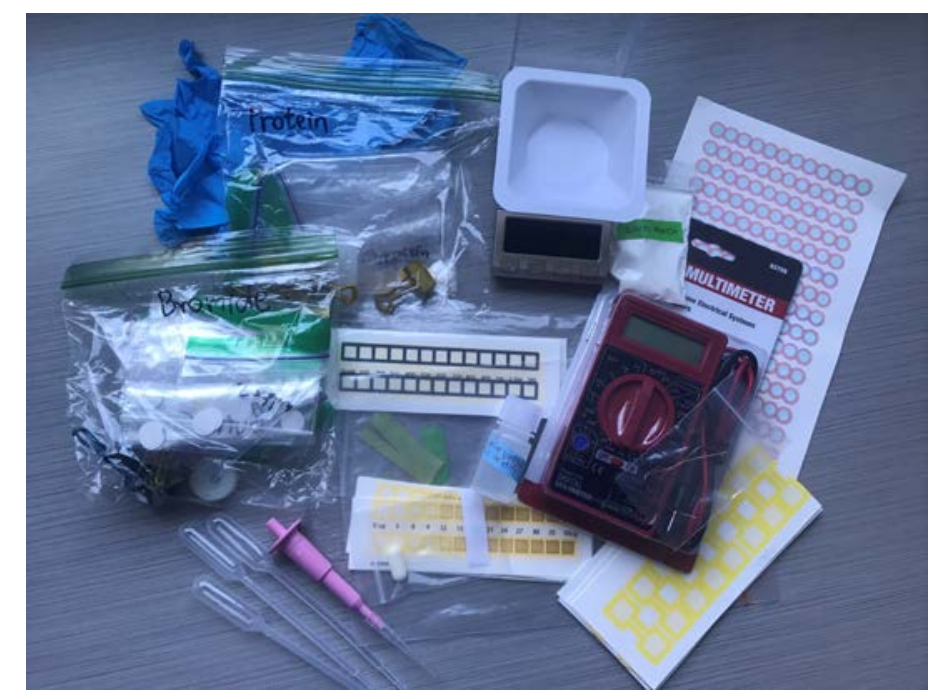

Figure 3. Example of a MICRO laboratory kit prepared for shipment.

Consistent with the project's commitment to equity and justice, all of the instructional materials adhere to best practices in accessibility. All videos include closed captions that were edited by a science student, and all written materials are formatted for easy use with a screen reader using section headers and alt text for all figures. 
Training and Implementation

We used three strategies in our efforts to develop a shared community approach to the MICRO project. First, in Summer 2020, we delivered a three-day online workshop to build community among the implementers, formulate learning goals, and give instructors hands-on experience with the experiments. Participants received kits with materials for several of the experiments before the workshop, and several sessions were spent in Zoom breakout rooms, performing the experiments in small groups. This gave the participants firsthand insight into their students' experience with the labs, and also gave the facilitators an opportunity to model different instructional approaches. Afternoon sessions focused on practical implementation strategies, such as how to prepare microfluidic devices, and on pedagogical topics such as writing measurable learning objectives, applying culturally sustaining pedagogy, and increasing the level of inquiry in the lab.

Second, we developed an online community platform using the Trello project management site. ${ }^{55}$ This platform provided convenient access to all of our shared resources and allowed participants to share links to helpful information, inexpensive equipment, or newly developed resources. All afternoon sessions from our August 2020 workshop were recorded and posted on the Trello site for future reference. A summary of the resources available on the MICRO webpage and Trello site can be found in the supporting information. Anyone interested in joining the community and accessing all of the materials can contact the authors for access.

Third, during the Fall semester, we held weekly drop-in Zoom “open hours” for implementers to ask questions, troubleshoot challenges, celebrate success stories, and connect with the MICRO community. These weekly meetings provided support for implementers who felt more uncertain but were also a great place for participants to suggest improvements and report their own innovations. After the first six weeks, we transitioned to a monthly meeting with a final wrap up at the end of the term. This type of formative project assessment was also very helpful in thinking about improvements for future semesters.

\section{PRELIMINARY RESULTS FROM IMPLEMENTATION}

The Fall 2020 cohort of beta testers included ten participating faculty members at nine institutions across the United States. Each beta tester implemented three to four of the MICRO laboratory experiments throughout the Fall semester. Some participating institutions had students complete the MICRO laboratory experiments in person, while others had students complete the MICRO laboratory experiments in their dorms/homes due to remote or hybrid learning models. Between the 9 participating institutions, just over 200 students in introductory analytical chemistry courses completed MICRO laboratory experiments. At least three institutions adapted the materials for use in General Chemistry courses, involving over 1,100 additional students. Because all MICRO materials are publicly available under a Creative Commons license, MICRO labs were also implemented by a number of other institutions that were not officially part of the project. Instructors were encouraged to modify the MICRO laboratory materials (learning objectives, pre-lab questions, etc.) to best suit their curriculum and student 
learning goals. All participants chose to either use the MICRO laboratory experiments as provided or made minor changes to the labs. All data was collected in accordance with Institutional Review Board guidelines.

Initial feedback from the Fall 2020 beta testers indicates that the use of MICRO laboratory experiments successfully encouraged student engagement in scientific practices and changed participant instructional practices. Participants highlighted that the inquiry-based nature of the labs forced their students to ask questions and work to solve problems collaboratively with their classmates. Many noted that, compared to previous semesters, students were more engaged with problem solving and experimental design. Several participants said this was many of their students' first experience with an inquiry-based laboratory experiment and observed that once students became comfortable with the trial-and-error nature of the labs, they had a sense of accomplishment and confidence. One participant reported that at the end of the semester, when her students started their final project involving designing an electrochemical device, her students "seemed more comfortable diving in than previous students.” However, many participants acknowledged that students initially were not comfortable with the iterative process and wanted to "throw in the towel" when they did not receive the anticipated results right away. We believe this speaks to the prevalence of cookbook-style laboratory experiments in laboratory learning and the importance of providing faculty with the tools to facilitate inquiry-based learning.

Despite this initial feeling of uncertainty, students were able to collect quality data using the microfluidic devices and analyze the data to draw relevant conclusions. Some beta testers indicated that labs such as the “Vinegar Titration Lab” allowed students to transfer their knowledge from traditional titration labs earlier in the semester to new microfluidic technology, and provided them with a fresh perspective on key analytical concepts. Testers observed that the iterative style of the MICRO labs encouraged students to consider sources of error in a more meaningful way. As one participant stated, “I also think they are used to just blaming things on 'error' and when something doesn't work as expected and just leaving it at that; they've never been forced to really think about what caused the error and how they could adapt the experiment to avoid it.” Another participant noted, "students definitely appreciated that the most accurate is not always the best—sometimes availability is the most valuable characteristic of an analysis.” Overall, beta testers have reported positive feedback in terms of enhanced student learning.

We also heard encouraging feedback on the faculty side of implementation. Prior to participating in the MICRO project, most of our participants were relying on cookbook-style experiments in their laboratory courses. Faculty credited the MICRO resources and professional development opportunities with enabling the transition from traditional cookbook-style labs to inquiry-based labs as well as providing guidance for remote laboratory learning. One participant said, "I certainly would not have been able to make these completely on my own. Having the experience and good instruction made this possible.” Faculty appreciated having resources for students completing laboratory courses remotely. One participant stated, "I am very grateful to give them the opportunity to get their hands wet and work at home during this crazy pandemic time.” 
While providing labs for remote learning was an essential goal for the MICRO project, a more central aim was to transform laboratory learning from traditional cookbook-style labs to inquiry-based labs. Early indicators are promising that participation in the project is having a broader impact on instructional practice-as one participant stated, "Implementing these labs has forced me to move even further from cookbook style labs, which I had been slowly working on.” This instructor goes on to say, "I've pretty much totally transformed two courses and part of my independent research at this point, and have no plans of going back. I came into this desperate for something to hold me over until the pandemic passed, but this will be something I stick with long term. My involvement (plus the pandemic) also gave me the push I needed to totally restructure my labs in a way that I think much better prepares the students for research and/or their future careers.” Many participants noted that they made significant changes to previously used laboratory experiments this semester because of what they learned and experienced through their involvement in the MICRO project.

When the Fall 2020 beta testers were asked about their likeliness to continue to use MICRO labs in future courses, most participants expressed a desire to continue incorporating MICRO labs in their chemistry courses, even when distance learning is no longer required. One participant noted, "I think we will continue using microfluidics labs in-person, though, because they liked them and I like having the model of what an inquirybased lab really looks like.” Another participant noted the benefit of an alternative approach to data collection and analysis, saying, "I think it also gives students a fresh perspective on chemical analysis - it does not need to be done with specialized glassware or fancy instruments.”

\section{CONCLUSIONS}

The MICRO project has developed a set of seven publicly available, inquiry-based experiments which use paper microfluidic devices to teach traditional analytical chemistry content while developing scientific skills. Each lab is situated within a social justice context and utilizes best practices in producing accessible content for students using adaptive technology. Current efforts are underway to develop additional experiments that address other topics typically covered in analytical chemistry. Because MICRO labs provide a safe and cost-effective way to deliver inquiry-based analytical laboratories, we anticipate that their appeal will continue beyond the context of the pandemic.

During Fall 2020, twelve institutions used these materials in analytical and general chemistry courses, and at least fifteen plan to use them during Spring 2021. Implementation results indicate that students were able to successfully use the lab materials and faculty perception suggests that the experiments increased the level of engagement and comfort with experimental design. Experience with inquiry-based labs may encourage faculty to continue to use these educational practices going forward. 


\section{ASSOCIATED CONTENT}

Supporting Information

The Supporting Information is available on the ACS Publications website at DOI:

10.1021/acs.jchemed.XXXXXXX.

SI1-MICRO Labs and Corresponding Levels of Inquiry and Scientific Practices (DOCX) — Information on inquiry level and scientific practices targeted by each experiment.

SI2-MICRO website and Trello site resource list (DOCX) - Summary of resources available through the MICRO webpage and Trello site.

SI_all_MICRO_lab_docs (DOCX) — Student procedures and instructor notes for all seven MICRO experiments.

\section{AUTHOR INFORMATION}

\section{Corresponding Author}

*Kimberley A. Frederick - Chemistry Department, Skidmore College, 815 North Broadway, Saratoga Springs, New York 12866, United States; orcid.org/0000-0002-2722-5125; E-mail: kfreder1@skidmore.edu

\section{Authors}

Rachel M. Roller - Department of Chemistry and Biochemistry, University of Notre Dame, Notre Dame, Indiana, 46556, United States

Saichon Sumantakul - Department of Chemistry, Oregon State University, Corvallis, Oregon 97331, United States

Michelle Tran - Department of Chemistry, Oregon State University, Corvallis, Oregon 97331, United States

Andrea Van Wyk - Department of Chemistry, University of Iowa, Iowa City, Iowa 52242, United States

Jessica Zinna - Department of Chemistry and Biochemistry, University of Notre Dame, Notre Dame, Indiana, 46556, United States

Destiny A. Donelson - Chemistry Department, Skidmore College, 815 North Broadway, Saratoga Springs, New York 12866, United States

Sarah G. Finnegan - Chemistry Department, Skidmore College, 815 North Broadway, Saratoga Springs, New York 12866, United States

Gregory Foley - Chemistry Department, Skidmore College, 815 North Broadway, Saratoga Springs, New York 12866, United States

Olivia R. Frechette - Chemistry Department, Skidmore College, 815 North Broadway, Saratoga Springs, New York 12866, United States

Jessica Gaetgens - Chemistry Department, Skidmore College, 815 North Broadway, Saratoga Springs, New York 12866, United States 
Jiani Jang - Department of Chemistry, Oregon State University, Corvallis, Oregon 97331, United States

Katheryn C. Rinaolo - Chemistry Department, Skidmore College, 815 North Broadway, Saratoga Springs, New York 12866, United States

Reneé S. Cole - Department of Chemistry, University of Iowa, Iowa City, Iowa 52242, United States

Marya Lieberman - Department of Chemistry and Biochemistry, University of Notre Dame, Notre Dame, Indiana, 46556, United States

Vincent T. Remcho - Department of Chemistry, Oregon State University, Corvallis, Oregon 97331, United States

\section{Author Contributions}

University of Notre Dame (R.M.R., J.Z., and M.L.) created wax-printed designs, produced $\mu$ PADs for lab development, training sessions, and implementation, developed the vinegar titration, Ksp of cream of tartar, and electrochemistry lab experiments, and developed and delivered faculty training materials.

Skidmore College (D.A.D, S.G.F., G.F., O.R.F., J.G., K.C.R., and K.A.F.) produced all of the student materials and instructor materials unless otherwise specified, created all of the student videos, developed the Ksp of baking soda and make-your-own microfluidic device labs, designed the website, curated the Trello site, and developed and delivered faculty training materials.

University of Iowa (A.VW. and R.S.C.) developed all of the training materials for pedagogical support, provided support for the development of student and faculty materials, and conducted all of the project assessment.

Oregon State University (M.T., S.S., J.J., and V.T.R.) developed the flow-through device labs and associated materials, produced devices for training for the determination of protein in milk and bromide in water lab experiments, and developed and delivered faculty training materials.

R.M.R., A.VW., J.Z., R.S.C., M.L., and K.A.F. assisted in the preparation of the manuscript. All authors approved the manuscript before submission. Graduate students, undergraduate researchers, and faculty are listed alphabetically.

\section{Conflict of Interest}

Marya Lieberman is the CEO of Paper Analytics LLC (Indiana), a not-for-profit company that sells the supplies for MICRO labs at cost.

\section{ACKNOWLEDGMENTS}

The authors acknowledge support from the Howard Hughes Medical Institute and the National Science Foundation (NSF DUE-1624898, 1624956, 2037528). J.Z. and R.M.R. acknowledge fellowships from the Arthur J. Schmitt Foundation. S.G.F. acknowledges support from the Schupf Scholar Program at Skidmore College. 


\section{REFERENCES}

(1) Howitz, W. J.; Thane, T. A.; Frey, T. L.; Wang, X. S.; Gonzales, J. C.; Tretbar, C. A.; Seith, D. D.; Saluga, S. J.; Lam, S.; Nguyen, M. M.; Tieu, P.; Link, R. D.; Edwards, K. D. Online in No Time: Design and Implementation of a Remote Learning First Quarter General Chemistry Laboratory and Second Quarter Organic Chemistry Laboratory. J. Chem. Educ. 2020, 97 (9), 2624-2634.

https://doi.org/10.1021/acs.jchemed.0c00895.

(2) Jeffery, K. A.; Bauer, C. F. Students’ Responses to Emergency Remote Online Teaching Reveal Critical Factors for All Teaching. J. Chem. Educ. 2020, 97 (9), 2472-2485.

https://doi.org/10.1021/acs.jchemed.0c00736.

(3) McCusker, C. E.; Mohseni, R. Reflections on Transitioning to Online General Chemistry in Southern Appalachia. J. Chem. Educ. 2020, 97 (9), 2913-2916. https://doi.org/10.1021/acs.jchemed.0c00743.

(4) Wang, L. Q.; Ren, J. Strategies, Practice and Lessons Learned from Remote Teaching of the General Chemistry Laboratory Course at Brown University. J. Chem. Educ. 2020, 97 (9), 3002-3006. https://doi.org/10.1021/acs.jchemed.0c00746.

(5) Dukes, A. D. Teaching an Instrumental Analysis Laboratory Course without Instruments during the COVID-19 Pandemic. J. Chem. Educ. 2020, 97 (9), 2967-2970.

https://doi.org/10.1021/acs.jchemed.0c00648.

(6) Perri, M. J. Online Data Generation in Quantitative Analysis: Excel Spreadsheets and an Online HPLC Simulator Using a Jupyter Notebook on the Chem Compute Web Site. J. Chem. Educ. 2020, 97 (9), 2950 2954. https://doi.org/10.1021/acs.jchemed.0c00565.

(7) Buchberger, A. R.; Evans, T.; Doolittle, P. Analytical Chemistry Online? Lessons Learned from Transitioning a Project Lab Online Due to COVID-19. J. Chem. Educ. 2020, 97 (9), 2976-2980. https://doi.org/10.1021/acs.jchemed.0c00799.

(8) Villanueva, O.; Zimmermann, K. Transitioning an Upper-Level, Integrated Laboratory Course to Remote and Online Instruction during the COVID-19 Pandemic. J. Chem. Educ. 2020, 97 (9), 3114-3120. https://doi.org/10.1021/acs.jchemed.0c00740.

(9) Valle-Suárez, R. M.; Calderón-Mendoza, G. L.; Lanza-Sorto, N. A.; Ponce-Rodríguez, H. D. Teaching Instrumental Analytical Chemistry in the Framework of COVID-19: Experiences and Outlook. J. Chem. Educ. 2020, 97 (9), 2723-2726. https://doi.org/10.1021/acs.jchemed.0c00707.

(10) Destino, J. F.; Cunningham, K. At-Home Colorimetric and Absorbance-Based Analyses: An Opportunity 
for Inquiry-Based, Laboratory-Style Learning. J. Chem. Educ. 2020, 97 (9), 2960-2966. https://doi.org/10.1021/acs.jchemed.0c00604.

(11) Miles, D. T.; Wells, W. G. Lab-in-a-Box: A Guide for Remote Laboratory Instruction in an Instrumental Analysis Course. J. Chem. Educ. 2020, 97 (9), 2971-2975. https://doi.org/10.1021/acs.jchemed.0c00709.

(12) Brewer, S. E.; Cinel, B.; Harrison, M.; Mohr, C. L. First Year Chemistry Laboratory Courses for Distance Learners : Development and Transfer Credit Acceptance. Int. Rev. Res. Open Distance Learn. 2013, 14 (3), 488-507. https://doi.org/10.19173/irrodl.v14i3.1446.

(13) Phipps, L. R. Creating and Teaching a Web-Based, University-Level Introductory Chemistry Course That Incorporates Laboratory Exercises and Active Learning Pedagogies. J. Chem. Educ. 2013, 90 (5), 568573. https://doi.org/10.1021/ed200614r.

(14) Carrigan, K. Review of LabPaq Science Lab Kits for Chemistry LabPaq Science Lab Kits for Chemistry. Http://Www.Labpaq.Com/ (Accessed Jan 2012). Hands-On Labs, Inc.: Englewood, Colorado. Kits for PCC Include: Pcc-Ck-100, Cost \$169; Pcc-Ck-104, Cost \$159; Pcc-Ck105, Cos. J. Chem. Educ. 2012, 89 (3), 314-315. https://doi.org/10.1021/ed200870x.

(15) Ferguson, M. J. Review of Introductory Chemistry Version 4 Kit Introductory Chemistry Version 4. EScience Labs, LLC: Sheridan, Colorado, 2009. 97 Pp. ISBN: 978-0984867516 (Ebook/Kit). \$98. J. Chem. Educ. 2012, 89 (3), 312-313. https://doi.org/10.1021/ed200862s.

(16) Abdulwahed, M.; Nagy, Z. K. Applying Kolb’s Experiential Learning Cycle for Laboratory Education. $J$. Eng. Educ. 2009, 98 (3), 283-294. https://doi.org/10.1002/j.2168-9830.2009.tb01025.x.

(17) Gupta, T.; Burke, K. A.; Mehta, A.; Greenbowe, T. J. Impact of Guided-Inquiry-Based Instruction with a Writing and Reflection Emphasis on Chemistry Students' Critical Thinking Abilities. J. Chem. Educ. 2015, 92 (1), 32-38. https://doi.org/10.1021/ed500059r.

(18) Hofstein, A. The Laboratory in Chemistry Education: Thirty Years of Experience with Developments, Implementation, and Research. Chem. Educ. Res. Pr. 2004, 5 (3), 247-264. https://doi.org/10.1039/B4RP90027H.

(19) Greenbowe, T. J.; Poock, J. R.; Burke, K. A.; Hand, B. M. Using the Science Writing Heuristic in the General Chemistry Laboratory To Improve Students’ Academic Performance. J. Chem. Educ. 2007, 84 (8), 1371. https://doi.org/10.1021/ed084p1371.

(20) Reid, N.; Shah, I. The Role of Laboratory Work in University Chemistry. Chem. Educ. Res. Pr. 2007, 8 (2), 172-185. https://doi.org/10.1039/B5RP90026C. 
(21) Walker, J. P.; Sampson, V.; Zimmerman, C. O. Argument-Driven Inquiry: An Introduction to a New Instructional Model for Use in Undergraduate Chemistry Labs. J. Chem. Educ. 2011, 88 (8), 1048-1056. https://doi.org/10.1021/ed100622h.

(22) Walker, J. P.; Sampson, V.; Southerland, S.; Enderle, P. J. Using the Laboratory to Engage All Students in Science Practices. Chem. Educ. Res. Pract. 2016, 17 (4), 1098-1113.

https://doi.org/10.1039/C6RP00093B.

(23) National Research Council. A Framework for K-12 Science Education: Practices, Crosscutting Concepts, and Core Ideas; Quinn, H., Schweingruber, H., Keller, T., Eds.; National Academies Press, 2012. https://doi.org/10.17226/13165.

(24) Cooper, M. M.; Caballero, M. D.; Ebert-May, D.; Fata-Hartley, C. L.; Jardeleza, S. E.; Krajcik, J. S.; Laverty, J. T.; Matz, R. L.; Posey, L. A.; Underwood, S. M. Challenge Faculty to Transform STEM Learning. Science (80-. ). 2015, 350 (6258), 281-282. https://doi.org/10.1126/science.aab0933.

(25) McDonald, J. Point of View: The Next Generation Science Standards: Impact on College Science Teaching. J. Coll. Sci. Teach. 2015, 045 (01), 2015. https://doi.org/10.2505/4/jcst15_045_01_13.

(26) Laverty, J. T.; Underwood, S. M.; Matz, R. L.; Posey, L. A.; Carmel, J. H.; Caballero, M. D.; Fata-Hartley, C. L.; Ebert-May, D.; Jardeleza, S. E.; Cooper, M. M. Characterizing College Science Assessments: The Three-Dimensional Learning Assessment Protocol. PLoS One 2016, 11 (9), e0162333. https://doi.org/10.1371/journal.pone.0162333.

(27) Sarkar, M.; Overton, T.; Thompson, C.; Rayner, G. Graduate Employability: Views of Recent Science Graduates and Employers. Int. J. Innov. Sci. Math. Educ. 2016, 24 (3), 31-48.

(28) Kondo, A. E.; Fair, J. D. Insight into the Chemistry Skills Gap: The Duality between Expected and Desired Skills. J. Chem. Educ. 2017, 94 (3), 304-310. https://doi.org/10.1021/acs.jchemed.6b00566.

(29) Bruck, L. B.; Bretz, S. L.; Towns, M. H. Characterizing the Level of Inquiry in the Undergraduate Laboratory. J. Coll. Sci. Teach. 2008, 38 (1), 52-58.

(30) Bruck, L. B.; Bretz, S. L.; Towns, M. H. A Rubric to Guide Curriculum Development of Undergraduate Chemistry Laboratory: Focus on Inquiry. In Chemistry Education in the ICT Age; Gupta-Bhowon, M., Jhaumeer-Laulloo, S., Li Kam Wah, H., Ramasami, P., Eds.; Springer Netherlands: Dordrecht, 2009; pp 75-83. https://doi.org/10.1007/978-1-4020-9732-4.

(31) Carmel, J. H.; Herrington, D. G.; Posey, L. A.; Ward, J. S.; Pollock, A. M.; Cooper, M. M. Helping Students to "Do Science”: Characterizing Scientific Practices in General Chemistry Laboratory Curricula. 
J. Chem. Educ. 2019, 96 (3), 423-434. https://doi.org/10.1021/acs.jchemed.8b00912.

(32) DeChenne, S. E.; Carew, J.; Stains, M. Research and Teaching: Published Freshman Lab Exercises as Indicators of Awareness and Adoption of Instructional Practices Grounded in Discipline-Based Education Research. J. Coll. Sci. Teach. 2014, 043 (09), 89-99. https://doi.org/10.2505/4/jcst14_043_06_89.

(33) Madden, P. E.; Wong, C.; Vera Cruz, A. C.; Olle, C. D.; Barnett, M. Social Justice Driven Learning (StemJ): A Curricular Framework for Teaching Stem in a Social Justice Driven, Urban, College Access Program. Catal. A Soc. Justice Forum 2017, 7 (1), 24-37.

(34) Barton, A. C.; Upadhyay, B. Teaching and Learning Science for Social Justice: Introduction to the Special Issue. Equity Excell. Educ. 2010, 43 (1), 1-5. https://doi.org/10.1080/10665680903484917.

(35) Ali, Z. M.; Harris, V. H.; Lalonde, R. L. Beyond Green Chemistry: Teaching Social Justice in Organic Chemistry. J. Chem. Educ. 2020, 97 (11), 3984-3991. https://doi.org/10.1021/acs.jchemed.9b00715.

(36) Gerdon, A. E. Connecting Chemistry to Social Justice in a Seminar Course for Chemistry Majors. J. Chem. Educ. 2020, 97 (12), 4316-4320. https://doi.org/10.1021/acs.jchemed.0c01043.

(37) Clark, G. A.; Humphries, M. L.; Perez, J.; Udoetuk, S.; Bhatt, K.; Domingo, J. P.; Garcia, M.; Daubenmire, P. L.; Mansuri, N.; King, M. Urinalysis and Prenatal Health: Evaluation of a Simple Experiment That Connects Organic Functional Groups to Health Equity. J. Chem. Educ. 2020, 97 (1), 4855. https://doi.org/10.1021/acs.jchemed.9b00408.

(38) Koesdjojo, M. T.; Pengpumkiat, S.; Wu, Y.; Boonloed, A.; Huynh, D.; Remcho, T. P.; Remcho, V. T. Cost Effective Paper-Based Colorimetric Microfluidic Devices and Mobile Phone Camera Readers for the Classroom. J. Chem. Educ. 2015, 92 (4), 737-741. https://doi.org/10.1021/ed500401d.

(39) Cai, L.; Wu, Y.; Xu, C.; Chen, Z. A Simple Paper-Based Microfluidic Device for the Determination of the Total Amino Acid Content in a Tea Leaf Extract. J. Chem. Educ. 2013, 90 (2), 232-234. https://doi.org/10.1021/ed300385j.

(40) Ravgiala, R. R.; Weisburd, S.; Sleeper, R.; Martinez, A.; Rozkiewicz, D.; Whitesides, G. M.; Hollar, K. A. Using Paper-Based Diagnostics with High School Students to Model Forensic Investigation and Colorimetric Analysis. J. Chem. Educ. 2014, 91 (1), 107-111. https://doi.org/10.1021/ed300261a.

(41) Xu, C.; Lin, W.; Cai, L. Demonstrating Electrophoretic Separation in a Straight Paper Channel Delimited by a Hydrophobic Wax Barrier. J. Chem. Educ. 2016, 93 (5), 903-905. https://doi.org/10.1021/acs.jchemed.5b00674. 
(42) Lai, H.; Li, Z.; Zhu, S.; Cai, L.; Xu, C.; Zhou, Q. Naked-Eye Detection of Aluminum in Gastric Drugs on a Paper-Based Analytical Device. J. Chem. Educ. 2020, 97 (9), 295-299.

https://doi.org/10.1021/acs.jchemed.9b00569.

(43) Armenta, S.; Esteve-Turrillas, F. A.; Herrero-Martínez, J. M. Development and Evaluation of Paper-Based Devices for Iron(III) Determination in an Advanced Undergraduate Laboratory. J. Chem. Educ. 2020, 97 (10), 3852-3857. https://doi.org/10.1021/acs.jchemed.0c00369.

(44) Bliese, S. L.; O’Donnell, D.; Weaver, A. A.; Lieberman, M. Paper Millifluidics Lab: Using a Library of Color Tests to Find Adulterated Antibiotics. J. Chem. Educ. 2020, 97 (3), 786-792. https://doi.org/10.1021/acs.jchemed.9b00433.

(45) Myers, N. M.; Kernisan, E. N.; Lieberman, M. Lab on Paper: Iodometric Titration on a Printed Card. Anal. Chem. 2015, 87 (7), 3764-3770. https://doi.org/10.1021/ac504269q.

(46) Loh, L. J.; Bandara, G. C.; Weber, G. L.; Remcho, V. T. Detection of Water Contamination from Hydraulic Fracturing Wastewater: A uPAD for Bromide Analysis in Natural Waters. Analyst 2015, 140 (16), 5501-5507. https://doi.org/10.1039/c5an00807g.

(47) Brownell, S. E.; Tanner, K. D. Barriers to Faculty Pedagogical Change: Lack of Training, Time, Incentives, and...Tensions with Professional Identity? CBE Life Sci. Educ. 2012, 11 (4), 339-346. https://doi.org/10.1187/cbe.12-09-0163.

(48) Henderson, C.; Dancy, M.; Niewiadomska-Bugaj, M. Use of Research-Based Instructional Strategies in Introductory Physics: Where Do Faculty Leave the Innovation-Decision Process? Phys. Rev. Spec. Top. Phys. Educ. Res. 2012, 8 (2), 1-15. https://doi.org/10.1103/PhysRevSTPER.8.020104.

(49) Froyd, J. E.; Henderson, C.; Cole, R. S.; Friedrichsen, D.; Khatri, R.; Stanford, C. From Dissemination to Propagation: A New Paradigm for Education Developers. Chang. Mag. High. Learn. 2017, 49 (4), 35-42. https://doi.org/10.1080/00091383.2017.1357098.

(50) Macklin, A. Communities of Practice. In Theoretical Frameworks for Research in Chemistry and Science Education; Bodner, G. M., Orgill, M., Eds.; Pearson: Upper Saddle River, NJ, 2007; pp 195-217. https://doi.org/10.1016/S0187-893X(18)30013-2.

(51) Trust, T.; Horrocks, B. Six Key Elements Identified in an Active and Thriving Blended Community of Practice. TechTrends 2019, 63 (2), 108-115. https://doi.org/10.1007/s11528-018-0265-x.

(52) Bosman, L.; Voglewede, P. How Can a Faculty Community of Practice Change Classroom Practices? Coll. Teach. 2019, 67 (3), 177-187. https://doi.org/10.1080/87567555.2019.1594149. 
(53) Tomkin, J. H.; Beilstein, S. O.; Morphew, J. W.; Herman, G. L. Evidence That Communities of Practice Are Associated with Active Learning in Large STEM Lectures. Int. J. STEM Educ. 2019, 6 (1), 1. https://doi.org/10.1186/s40594-018-0154-z.

(54) Frederick, K.; Cole, R. S.; Lieberman, M.; Remcho, V. T. MICRO Engaged Lab Learning https://sites.google.com/view/micro-engaged-lab-learning/home.

(55) MICRO Beta Testers Trello Board https://rello.com/invite/b/vgv3Ncyd/97d403bc7ce94733fa119c3752ff69e5/micro-beta-testers Contact the authors for access. 